\title{
Dokonywana przez Rząd Republiki Litewskiej reforma przedsiębiorstw zarządzanych przez państwo
}

\author{
Agnè Juškevičiūtè-Vilienè \\ Uniwersytet Wileński, Wydział Prawa \\ Katedra Prawa Publicznego
}

\section{Wstęp}

Artykuł 5 Konstytucji Republiki Litewskiej głosi że: „Władzę państwową na Litwie sprawują Sejm, Prezydent, Rząd i Sąd”. Wspomniany artykuł określający podstawową zasadę organizacji demokratycznego państwa prawa - zasadę podziału władzy - ma na celu stworzenie sprawnie działającego mechanizmu państwowego. W Konstytucji Litwy określono podstawy systemu władzy wykonawczej oraz uprawnienia najwyższych jej organów. Ustrój konstytucyjny na Litwie cechuje dualistyczny model władzy wykonawczej: tę władzę sprawują Prezydent Republiki Litewskiej i Rząd ${ }^{1}$. Rząd pełni bardzo ważną rolę w systemie władzy publicznej, gdyż jego działalność wywiera znaczący wpływ na rozwój państwa. Rząd jest kolegialnym wykonawczo-porządkowym organem (art. 91 Konstytucji Litwy), realizującym postanowienia ustaw i innych aktów prawnych, prowadzącym sprawy krajowe. Uprawnienia Rządu są określone w konstytucji i ustawach. Działalność Rządu związana z realizacją przewidzianych wobec niego w konstytucji i ustawodawstwie kompetencji polega na prowadzeniu spraw z zakresu zarządzania państwem.

W art. 94, art. 84 pkt 3, art. 123 ust. 1, art. 128 ust. 1 i in. Konstytucji Litwy określono podstawowe kierunki działalności Rządu, z kolei w ustawie o Rządzie sprecyzowano sformułowania zawarte w konstytucji oraz szczegółowo określono konstytucyjne pełnomocnictwa Rządu. Uprawnienia Rządu, przewidziane w konstytucji i ustawie o Rządzie, są uprawnieniami ogólnymi, z kolei określone w poszczególnych ustawach - są uprawnieniami szczególnymi². Należy wspomnieć, iż

1 Orzeczenie Sądu Konstytucyjnego Republiki Litewskiej z 13 grudnia 2004 r. Terminem „Rząd” określa się na Litwie organ odpowiadający polskiej „Radzie Ministrów”, z tego względu wyraz ten będzie zapisywany wielką literą.

2 D. Beinoravičius et al., Lietuvos konstitucinè teisè, Vilnius 2017, s. 529. 
konstytucyjna lista zadań Rządu nie jest ostateczna, gdyż art. 94 ust. 7 Konstytucji Litwy głosi, że wykonuje on też inne obowiązki, powierzone zgodnie z konstytucją i innymi ustawami.

O podobnych konstytucyjnych regulacjach uprawnień Rządu decyduje różnorodność zarządzanych dziedzin i funkcji, która ciągle może ulegać zmianom. Wykonywane przez Rząd uprawnienia konstytucyjne mogą zmieniać się w zależności od sytuacji gospodarczej i społecznej państwa, rozwiązywanych problemów oraz wielu innych okoliczności, w przypadku zmiany których może zmienić się także treść i zakres uprawnień rządowych. Rząd, jako organ władzy wykonawczej, zgodnie z konstytucją inter alia dysponuje szerokim zakresem swobodnego uznania w kształtowaniu oraz prowadzeniu polityki gospodarczej państwa i odpowiednio regulowaniu działalności gospodarczej ${ }^{3}$. W art. 94 pkt 1 Konstytucji Litwy wskazano, że Rząd Republiki Litewskiej „zajmuje się sprawami krajowymi”. To konstytucyjne sformułowanie obejmuje wiele obszarów działalności - od kształtowania polityki gospodarczej poczynając, na zapewnieniu mieszkańcom kraju opieki medycznej kończąc.

W art. 22 ustawy o Rządzie, konkretyzującym działalność tego organu, przewidziano, że Rząd na podstawie ustaw dysponuje majątkiem państwa, określa tryb zarządzania nim i jego wykorzystywania. Rodzi się pytanie, co to jest majątek państwa? Należy podkreślić, że takiego pojęcia Konstytucja Litwy expressis verbis nie zawiera. Jaki jest zatem status prawny tego majątku w litewskim systemie prawnym?

Państwo litewskie jest ważnym akcjonariuszem spółek akcyjnych i spółek z ograniczoną odpowiedzialnością oraz właścicielem przedsiębiorstw państwowych, zarządzającym znaczną częścią krajowego majątku o przeznaczeniu komercyjnym ${ }^{4}$. Opublikowany po raz pierwszy w 2010 r. przegląd państwowego majątku o przeznaczeniu handlowym ujawnił, że wyniki działalności większości przedsiębiorstw zarządzanych przez państwo (dalej: PZP) były słabe. Kierowany przez Andriusa Kubiliusa XV Rząd rozpoczął reformę PZP, której celem była skuteczniejsza ich działalność. Właśnie ten Rząd zainicjował większość etapów reformy, która miała zapewnić działalności tych przedsiębiorstw większą przejrzystość i skuteczność. Rodzą się dalsze pytania: co to jest PZP, jaki ma status prawny i jakie zajmuje miejsce w gospodarce rynkowej? Realizowana przez Rządy reforma PZP zachęca do zastanowienia się, jakie środki prawne podjęto $\mathrm{w}$ jej ramach oraz czy były one odpowiednie w dążeniu do osiągnięcia postawionych celów.

Celem niniejszego opracowania jest analiza podstaw prawnych dotyczących przedsiębiorstw zarządzanych przez państwo jako części majątku państwowego w przepisach prawa litewskiego oraz ukazanie podstawy prawnej realizowanej przez Rządy reformy PZP.

3 Orzeczenie Sądu Konstytucyjnego Republiki Litewskiej z 23 maja 2007 r.

4 M. Anužis, V. Sinkevičius, Valstybės valdomos įmonès. Nepriklausomų valdybos narių atrankos gairès, nuosavybės gairių analizè ir atitiktis EBPO gairèms, Vilnius 2015, s. 3. 
Dla realizacji tego celu należy postawić przed sobą następujące zadania:

1. Omówienie koncepcji majątku państwowego oraz kompetencji Rządu w zarządzaniu, wykorzystywaniu i dysponowaniu tym majątkiem.

2. Omówienie koncepcji PZP i jego miejsca w życiu gospodarczym Litwy.

3. Przedstawienie podstawowych celów realizowanej przez Rząd reformy PZP i jej etapów.

4. Po przeanalizowaniu aktów prawnych przyjętych przez Rząd pokazanie wad reformy.

Przedmiotem zamieszczonej tu analizy są określone w litewskich przepisach prawa cechy statusu prawnego PZP i reformy ich działalności.

$\mathrm{Na}$ Litwie dotychczas nie publikowano szczegółowych wyników badań poświęconych wspomnianej tematyce. Litewscy naukowcy omawiali poszczególne aspekty przedsiębiorstw zarządzanych przez państwo, np. Liudas Jurkonis (2012) badał wpływ kontroli zarządzania i autonomii przedsiębiorstw zarządzanych przez państwo na skuteczność działalności; M. Marčiulionyte, P. Oržekauskas i A. Junevičius (2013) analizowali możliwości doskonalenia zarządzania przedsiębiorstw zarządzanych przez państwo; L. Mažylytė (2013) oceniała rolę przedsiębiorstw zarządzanych przez państwo w kontekście wewnętrznego rynku unijnego; N. Laurišonytė (2014) zajmowała się polityzacją kierownictwa litewskich przedsiębiorstw zarządzanych przez państwo; S. Vaitkevičius i R. Birštonas (2015) analizowali ochronę publicznych interesów majątkowych i reprezentowanie przedsiębiorstw. Mimo wszystko w literaturze naukowej brakuje całościowego spojrzenia na PZP, ich miejsce w społecznych stosunkach prawno-gospodarczych oraz realizowaną przez Rząd reformę PZP i jej przebieg.

\section{Majątek państwowy i działalność Rządu}

Należy podkreślić, że w art. 46 ust. 1 Konstytucji Litwy wskazano, że gospodarka tego kraju oparta jest na własności prywatnoprawnej. Jest to jedyny przepis w Konstytucji, w którym da się bezpośrednio dostrzec podział własności na rodzaje $\mathrm{e}^{5}$, gdyż pojęcie „własność prywatna” jako przeciwieństwo przewiduje własność inną niż prywatna. S. Vaitkevičius i R. Birštonas zauważyli, że w Konstytucji Litwy

5 Należy zaznaczyć, że w przyjętej w 1940 r. pierwszej Konstytucji Litewskiej SRR, w przeciwieństwie do Konstytucji Litwy obowiązującej w okresie międzywojennym (konstytucje z 1922, 1928 i 1938 r.), obok własności prywatnej określono nową formę własności - własność socjalistyczną, w ramach której wyróżniono dwie formy: własność państwową i własność kooperatywną. Z kolei w Konstytucji Litewskiej SRR z 1978 r. wymieniono trzy formy własności: państwową, kołchozowo-kooperatywną oraz związków zawodowych i innych organizacji społecznych, tj. całkowicie wyeliminowano własność prywatną. Więcej na ten te- 
nie został nazwany żaden inny rodzaj własności, a przynajmniej expressis verbis nie zostały one wyróżnione w doktrynie Sądu Konstytucyjnego Litwy ${ }^{6}$.

Warto zaznaczyć, że w art. 47 ust. 1 Konstytucji Litwy jako wyłączną własność Republiki Litewskiej wskazano majątek (tj. głębiny ziemi, wody śródlądowe o znaczeniu państwowym, drogi, lasy i inne), na który składają się obiekty stanowiące własność państwa, które jednak nie stanowią osobnego rodzaju własności. Jednak na podstawie tego sformułowania konstytucyjnego można wnioskować, że Konstytucja określiła własność państwową, tj. Republiki Litewskiej, wobec której państwo ma wyłączne prawo własności i która nie może zostać przekazana osobie prywatnej. Art. 125 ust. 1 („Bank Litwy jest własnością państwa litewskiego”), art. 128 ust. 1 (regulacje wykonania państwowych zobowiązań majątkowych) i ust. 2 (regulacje zarządzania, wykorzystywania i dysponowania majątkiem państwowym) Konstytucji potwierdza, że prawo własności państwowej nie tylko istnieje, ale też ma dość specyficzny status.

Art. 23 Konstytucji Litwy, określający konstytucyjną gwarancję ochrony własności („Nietykalność własności”), nie różnicuje własności i jej ochrony według podmiotów. Sąd Konstytucyjny, dokonując wykładni tego przepisu Konstytucji, wspomniał, że „Postanowienia art. 23 Konstytucji wszystkim właścicielom - osobom fizycznym, osobom prawnym, jednostkom samorządu terytorialnego i państwu - gwarantuje ochronę własności"7. Zatem zgodnie z Konstytucją i interpretującą ją doktryną „ustawy powinny chronić prawa własności wszystkich właścicieli,

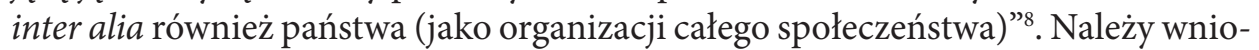
skować, że chociaż w Konstytucji nie wymieniono rodzajów własności, to jednak systemowa analiza przepisów konstytucyjnych i doktryny Sądu Konstytucyjnego wskazuje na przesłanki do różnicowania prawa własności według podmiotów, tj. na własność prywatną i państwową.

Pojęcie majątku państwowego częściej pojawia się w zwyczajnych aktach prawnych. Na przykład Kodeks cywilny Republiki Litewskiej (dalej: KC) przewiduje, że państwo i jego organy w stosunkach cywilnych biorą udział na równych podstawach, podobnie jak inne podmioty stosunków (art. 2.36 KC). Kodeks i orzecznictwo sądowe określiły zatem podział między funkcjami organów publicznych, które reguluje prawo publiczne oraz działalnością gospodarczą, regulowaną przez prawo cywilne. Państwo, zarządzając, wykorzystując i dysponując swoim majątkiem, nie ma i nie może mieć przewagi nad innymi podmiotami obrotu cywilnego (nie uniemożliwia to jednak pewnego zróżnicowania regulacji prawnych względem pań-

mat: A. Juškevičiūtè-Vilienè, Asmens ūkinės veiklos laisvės konstituciniai pagrindai Lietuvoje: ekonominès, istorinès ir lyginamosios ižvalgos, Vilnius 2017, s. 152-166.

6 S. Vaitkevičius, R. Birštonas, Valstybinio turto valdymas ir privatizavimas 1992-2012 metais, Vl „Registrų centras”, Vilnius 2015, s. 18.

7 Orzeczenie Sądu Konstytucyjnego Republiki Litewskiej z 27 maja 2002 r.

8 Orzeczenie Sądu Konstytucyjnego Republiki Litewskiej z 30 listopada 2008 r. 
stwa). W KC, podobnie jak w Konstytucji Litwy, nie ma podziału własności na rodzaje, jednak biorąc pod uwagę wyjątkowość państwa jako organizacji jednoczącej naród, jego dążenie do zabezpieczenia interesu publicznego poprzez prowadzenie działalności gospodarczej, w niektórych artykułach pojawia się pojęcie „własność publiczna" (art. 2.4, art. $4.100 \mathrm{KC)}$ ) z niektórych zaś norm prawnych wyraźnie wynika, że inaczej wyglądają regulacje dotyczące własności prywatnej i państwowej (np. art. 4.69, art. 6.546, art. $6.548 \mathrm{i}$ in. KC) ${ }^{9}$. W KC wyraźne jest zróżnicowanie prywatnych i publicznych osób prawnych, spółki utworzone przez państwo zaliczane są do podmiotów publicznych (art. $2.34 \mathrm{KC}$ ) oraz mają szczególną zdolność prawną, tj. nabycie, posiadanie lub ograniczenie praw i obowiązków jest określane w dokumentach założycielskich, w granicach wskazanych w celach działalności.

Bardziej szczegółowe podstawy regulacji własności publicznej zawarte są w ustawie o zarządzaniu, wykorzystywaniu i dysponowaniu majątkiem państwowym i samorządowym ${ }^{10}$. Zgodnie $\mathrm{z}$ art. 3 ust. 1 ww. ustawy majątek państwowy (podobnie jak samorządowy) jest dzielony na: 1) trwały materialny; 2) niematerialny; 3) finansowy; 4) obrotowy materialny.

Należy zaznaczyć, że majątek państwowy, w przeciwieństwie do prywatnego, jest zarządzany zgodnie $z$ uprzednio przyjętymi aktami prawnymi, dlatego to zarządzanie staje się przedmiotem prawa publicznego (a konkretniej: przedmiotem prawa publiczno-gospodarczego), chociaż jednocześnie nie dochodzi do zerwania związku tego majątku z prawem prywatnym ${ }^{11}$. Jak twierdzi J. Tittenbrun, jeżeli właścicielem majątku państwowego jest taki abstrakcyjny twór jak państwo, zarządzać tą własnością powinien Rząd, który odpowiada przed określoną grupą przedstawicieli narodu za skuteczne zarządzanie tym majątkiem i realizuje interes publiczny ${ }^{12}$. Taka teoretyczna myśl zawarta jest w art. 22 ustawy o Rządzie, w którym określono, że Rząd na podstawie przepisów prawa dysponuje majątkiem państwowym, określa tryb zarządzania nim i wykorzystywania go.

Majątek państwowy i zarządzanie nim przede wszystkim powinny być związane z realizacją funkcji publicznych, jednak niektóre dziedziny działalności państwa mają charakter komercyjny. Państwo, jako właściciel majątku, realizuje swoje prawa nie tylko za pośrednictwem różnych organów i urzędów, lecz także za pośrednictwem przedsiębiorstw w całości lub części kontrolowanych przez siebie (przedsiębiorstwa i spółki zarządzane przez państwo). Dzięki zarządzaniu majątkiem państwowym i jego wykorzystywaniu państwo bierze bezpośredni udział w rynkowych stosunkach gospodarczych (w zagranicznej literaturze prawniczej jest to określane

9 S. Vaitkevičius, R. Birštonas, Valstybinio turto valdymas..., s. 26-27.

10 Ustawa o zarządzaniu, wykorzystywaniu i dysponowaniu majątkiem państwowym i samorządowym, „Valstybės žinios” z 1994 r., nr IX-1895; „Valstybės žinios” z 2004 r., nr 4-24.

11 R. Hauser, Z. Niewiadomski, A. Wróbel (red.), Publiczne prawo gospodarcze. System prawa administracyjnego, t. 8A, Warszawa 2018, s. 763.

12 J. Tittenbrun, Przedsiębiorstwo publiczne w ujęciu teorii praw własnościowych, „Ruch Prawniczy, Ekonomiczny i Socjologiczny"1996, t. 3, s. 131. 
administrowaniem ekonomicznym) ${ }^{13}$. Państwo w taki sposób nie tylko reguluje stosunki gospodarcze i wspiera przedsiębiorczość, ale też rozwija określone wartości gospodarcze państwa. W art. 23 ust. 1 ustawy o zarządzaniu, wykorzystywaniu i dysponowaniu majątkiem państwowym i samorządowym przewidziano, że prawa majątkowe oraz niemajątkowe państwa w przedsiębiorstwach państwowych są realizowane w trybie określonym przez Rząd. Rząd ma zatem prawo, a nawet obowiązek podejmowania najważniejszych decyzji w zakresie zarządzania majątkiem państwowym - przedsiębiorstwami zarządzanymi przez państwo.

Należy wnioskować, że chociaż w konstytucyjnych normach prawa nie został explicite wskazany „majątek państwowy”, jednak systemowa analiza Konstytucji Litwy, interpretującego ją orzecznictwa konstytucyjnego oraz zwykłych aktów prawnych pozwala na wyróżnienie własności prywatnej i publicznej. Głównym zarządcą jednego z rodzajów majątku państwa, czyli przedsiębiorstw zarządzanych przez państwo, jest Rząd, który podejmuje najważniejsze decyzje w tej dziedzinie.

\section{Przedsiębiorstwa zarządzane przez państwo (PZP)}

Podstawowym zadaniem Rządu Republiki Litewskiej jest dążenie do tego, by majątek państwowy wytwarzał wartość na rzecz głównego właściciela - mieszkańców Litwy. Państwo z kolei jest największym na Litwie właścicielem majątku o przeznaczeniu komercyjnym, dlatego powinno wykazywać profesjonalizm i odpowiedzialność, aktywnie dążyć do powiększenia wartości majątku tych przedsiębiorstw, zaś zarządzanie nimi powinno być przejrzyste i zorientowane na jasne cele ${ }^{14}$.

Przedsiębiorstwo zarządzane przez państwo (stanowiące część majątku państwowego) to przedsiębiorstwo państwowe, spółka akcyjna lub spółka z ograniczoną odpowiedzialnością prowadząca działalność gospodarczo-handlową, w której państwo ma swoje udziały ${ }^{15}$. Przedsiębiorstwa te wytwarzają ważną wartość gospodarczą i w znacznym stopniu przyczyniają się do rozwoju gospodarczego kraju, realizacji ważnych projektów strategicznych. Państwo bierze udział w zarządzaniu tymi przedsiębiorstwami, mając na celu zapewnienie dostawy strategicznie ważnych dla kraju towarów i usług ${ }^{16}$.

13 R. Hauser, Z. Niewiadomski, A. Wróbel (red.), Publiczne prawo gospodarcze..., s. 757.

14 Postanowienie Rządu Republiki Litewskiej w sprawie zatwierdzenia koncepcji zwiększenia skuteczności przedsiębiorstw państwowych z 1 grudnia 2010 r., nr 1731, „Valstybęs žinios” z 2010 r., nr 145-7447.

15 Ibidem.

16 State-Owned Enterprises in the European Union: ensuring level playing field, Raport, http:// www.esparama.It/es_parama_pletra/failai/ESFproduktai/2_UM_valstybes-valdomos-imones_2013-03.pdf (dostęp: 10.06.2018). 
Na podstawie wyników badań przeprowadzonych w państwach w zakresie liczby pracowników i wielkości zarządzanego majątku, PZP największą rolę odgrywają w sektorze energetyki, transportu, telekomunikacji, produkcji, ropy naftowej i gazu ${ }^{17}$. Należy podkreślić, że - jak pokazuje doświadczenie międzynarodowe - PZP stanowią znaczną część PKB kraju i przyczyniają się do przyciągnięcia inwestycji:

- w krajach rozwiniętych PZP stanowią około 8\% PKB i 13\% inwestycji krajowych;

- w krajach rozwijających się PZP stanowią odpowiednio 9\% PKB i 17\% inwestycji krajowych;

- w krajach najmniej rozwiniętych PZP stanowią odpowiednio 14\% PKB i 28\% inwestycji krajowych ${ }^{18}$.

Jak wynika z badań przeprowadzonych przez L. Jurkonisa, PZP najczęściej działają w sektorze pocztowym i kolejowym, z kolei z sektora medycznego i alkoholowego państwo jako akcjonariusz już faktycznie zostało wypchnięte. Należy zaznaczyć, że w liberalizującej się gospodarce światowej liczba gałęzi gospodarki, w których PZP i spółki z kapitałem prywatnym ze sobą konkurują, szybko rośnie ${ }^{19}$.

Zgodnie z badaniami przeprowadzonymi przez Organizację Współpracy Gospodarczej i Rozwoju (dalej: OECD) oraz Bank Światowy ${ }^{20}$ PZP są ważne w gospodarce krajowej, ponieważ:

- przyczyniają się do rozwoju i utrzymania strategicznie ważnych, jednak ekonomicznie niezbyt korzystnych sektorów;

- rozwijają sektory, które wymagają znacznych wstępnych inwestycji, z kolei zwroty z zainwestowanego kapitału i prawa własności są trudne do oceny i nie są wyraźnie określone;

- realizują cele społeczne;

- przyczyniają się do zwiększenia konkurencyjności mniej rozwiniętych regionów;

- zapewniają dalszy rozwój nowych sektorów i inne.

Biorąc pod uwagę przywołane wyniki analizy, dostrzegamy, że PZP stanowią nieodłączny składnik gospodarki państwa. Ponadto eksperci z różnych krajów podkreślają, że ta tendencja jest dodatnia i w długotrwałej perspektywie PZP zachowają strategiczną wagę w kontekście gospodarki ogólnoświatowej ${ }^{21}$.

17 Valstybès valdomos imonès, Raport, http://www.vkc.sipa.lt/static/uploads/VKC_2016_LT_ A4_WEB.pdf (dostęp:10.06.2018).

18 L. Jurkonis, Valstybès valdomy imoniu valdymo kontrolès ir autonomijos poveikis veiklos efektyvumui, „Politologija” 2012, nr 2 (66), s. 3-31.

19 Ibidem.

20 Zgodnie z dokonanym przez OECD w latach 2008-2010 przeglądem największych gospodarek świata (wydzielając rolę PZP), a także raportem Banku Światowego Bureaucrats in Business.

21 L. Jurkonis, Valstybés valdomu ìmonių valdymo kontrolés..., s. 11-12. 
Przez długi czas uważano, że mając na celu zapewnienie rozwoju wolnego rynku i uniknięcie zbędnego trwonienia majątku państwa, jedynym „sposobem” na przedsiębiorstwa państwowe jest ich prywatyzacja. Jednak Organizacja Współpracy Ekonomicznej i Rozwoju przeanalizowała pomyślnie przeprowadzone w różnych krajach reformy PZP i uogólniła najlepsze doświadczenia w zaleceniach dobrego zarządzania przedsiębiorstwami państwowymi ${ }^{22}$ (dalej: zalecenia OECD), zgodnie z którymi PZP mają szanse na konkurencyjność nawet na rynku międzynarodowym oraz osiąganie wyników nie gorszych niż spółki prywatne ${ }^{23}$.

Wyniki przeprowadzonego przez OECD międzynarodowego sondażu pokazały, iż w niektórych przypadkach uznaje się, że PZP mają przewagę nad firmami prywatnymi, gdyż:

- cechuje je większa stałość działalności, zwłaszcza w kontekście dynamicznego i szybko zmieniającego się współcześnie otoczenia;

- są w większym stopniu nastawione na świadczenie usług, nie orientując się wyłącznie na minimalizację kosztów działalności;

- mają więcej możliwości realizacji długoterminowych, strategicznie ważnych projektów inwestycyjnych ${ }^{24}$.

$\mathrm{Na}$ Litwie do PZP zaliczane są dwa rodzaje przedsiębiorstw:

1. Przedsiębiorstwa państwowe - to przedsiębiorstwa utworzone na bazie majątku państwowego lub przekazane państwu zgodnie z przepisami prawa, będące własnością państwa. Majątkiem przekazanym tym przedsiębiorstwom oraz nabytym zarządzają, użytkują i dysponują nim na prawie po-

22 OECD w 2015 r. zaktualizowało Wytyczne dotyczące zarządzania korporacyjnego przedsiębiorstwami państwowymi (ang. OECD Guidelines on Corporate Governance of State-Owned Enterprises) - dokument określający podstawowe zasady zarządzania PZP. Wytyczne OECD dotyczą porozumienia między najbardziej postępowymi i najlepiej rozwiniętymi gospodarczo krajami i są uznawane za wzór na skalę międzynarodową. Zawierają konkretne propozycje dotyczące rozwiązywania poszczególnych problemów w zarządzaniu PZP, np. zalecenie, by państwo określiło swoją politykę własności i wyraźniej podzieliło funkcje realizacji oraz regulacji własności. Wytyczne zawierają też opis godnych naśladowania ról członków organów kolegialnych PZP (zarządu lub rady nadzorczej), zalecenia co do składu i procedur doboru członków. W dokumencie podkreślono, że powinny zostać stworzone jednakowe warunki konkurencji dla PZP i spółek sektora prywatnego. Należy brać pod uwagę interesy akcjonariuszy i stron powiązanych PZP oraz dążyć do możliwie największej przejrzystości. Te i inne zalecane zmiany byłyby pomocne państwom w zapewnieniu profesjonalnego zarządzania własnymi przedsiębiorstwami. Wszystkie państwa, które dążą do członkostwa w organizacji, są zobowiązane do realizacji zasad określonych w rekomendacjach OECD. Na tych wytycznych opierała się również Litwa, dokonując zmian w swojej polityce zarządzania PZP. Więcej: http://www.oecd.org/corporate/guidelines-corporate-governance-soes.htm; http://vkc. sipa.It/static/uploads/ataskaitos/VKC_2017_LT_WEB.pdf (dostęp: 10.06.2018).

23 Postanowienie Rządu Republiki Litewskiej w sprawie zatwierdzenia koncepcji zwiększenia skuteczności przedsiębiorstw państwowych...

24 L. Jurkonis, Valstybés valdomu įmonių valdymo kontrolès..., s. 11-12. 
wierniczym ${ }^{25}$. Prawa i obowiązki właściciela przedsiębiorstwa państwowego państwo realizuje za pośrednictwem Rządu (lub upoważnionego przez Rząd organu zarządzającego);

2. Inne przedsiębiorstwa, które są zarządzane w oparciu o kapitał akcyjny ( w formie spółek akcyjnych i spółek z ograniczoną odpowiedzialnością) - to organ publiczny, urząd lub inna osoba prawna, realizująca prawa majątkowe i niemajątkowe $\mathrm{z}$ akcji przedsiębiorstw państwowych będących własnością państwa, którym w przypadkach i w trybie przewidzianym przepisami prawa akcje zostały przekazane na prawie powierniczym do zarządzania, używania i dysponowania.

Wagę przedsiębiorstw zarządzanych przez państwo dla kraju oraz ich wyjątkową pozycję na ogólnym rynku podkreśla wielu litewskich badaczy. L. Mažylytė twierdzi, że chociaż PZP są równoprawnymi uczestnikami rynku, które mają na celu zwiększenie zysku, konkurencję cenową i zwiększenie liczby nabywców lub usługobiorców, to ich sytuacja względem innych przedstawicieli sektora prywatnego często jest wyjątkowa, jako że te przedsiębiorstwa niekiedy korzystają z ulg podatkowych lub otrzymują pożyczki na zasadach ulgowych, subsydia, mają większe możliwości szybszego uzyskania informacji, ponadto przedsiębiorstwa państwowe działające na rynkach monopolistycznych niekiedy są nadzorowane przez dodatkowe organy ${ }^{26}$. L. Jurkonis podkreśla, że często PZP są odbierane jako mające przewagę nad spółkami prywatnymi, ponieważ odznaczają się większą stałością działalności, są bardziej zainteresowane świadczeniem usług, nie orientują się wyłącznie na minimalizację kosztów działalności oraz mają więcej możliwości realizacji długoterminowych, strategicznie ważnych projektów ${ }^{27}$.

Uogólniając, można zauważyć, że na Litwie do przedsiębiorstw zarządzanych przez państwo są zaliczane nie tylko przedsiębiorstwa państwowe, ale też przedsiębiorstwa prowadzące działalność w strategicznych sektorach przemysłu krajowego na bazie kapitału akcyjnego (spółki akcyjne i spółki z ograniczoną odpowiedzialnością), których większość akcji ma Rząd. Przedsiębiorstwa zarządzane przez państwo nie tylko bezpośrednio przyczyniają się do realizacji istotnych dla państwa funkcji, lecz także mają znaczny bezpośredni i pośredni wpływ na gospodarkę krajową, dobrobyt mieszkańców oraz tworzenie bardziej sprzyjających warunków przedsiębiorczości.

25 Ustawa o zarządzaniu, wykorzystywaniu i dysponowaniu majątkiem państwowym i samorządowym...

26 L. Mažylytė, Valstybės valdomy imonių vaidmuo ES vidaus rinkos kontekste, 2013, http://www. esrinka.It/download/275/straipsnis_konkurencingumas_vvi.pdf (dostęp: 23.06.2018).

27 L. Jurkonis, Valstybés valdomy imoniu valdymo kontrolés..., s. 3-31. 


\section{Reforma przedsiębiorstw zarządzanych przez państwo}

Na Litwie przez dłuższy czas po odzyskaniu niepodległości podstawowe akty prawne regulujące działalność krajowych PZP nie były nowelizowane - brakowało przejrzystości, wobec przedsiębiorstw zarządzanych przez państwo nie stawiano najwyższych celów, nie istniał jeden scentralizowany organ analizujący ich działalność. Dopiero w 2010 r. po raz pierwszy Ministerstwo Gospodarki opublikowało przegląd majątku o przeznaczeniu komercyjnym, który ujawnił, że wyniki działalności większości PZP są słabe, z kolei zwrot z kapitału w 2009 r. wyniósł zaledwie 0,1\% i był znacznie niższy niż średni zwrot w Europie oraz przeciętny zwrot z kapitału litewskich przedsiębiorstw sektora prywatnego (ok. 9\%). Jak już zostało wspomniane, jednym z zadań Rządu jest dążenie do tego, by majątek państwowy tworzył wartość dla mieszkańców Litwy, stąd też zainicjowana przez Rząd reforma PZP.

Poza tym, poczynając od 2000 r. w programach Rządu Litwy jako jeden z największych priorytetów określono dążenie kraju do członkostwa w OECD. Sprawdzając przygotowanie Litwy do członkostwa w organizacji, OECD przyglądało się siedmiu sektorom, w tym regulacji działalności PZP. To był jeszcze jeden powód, dla którego Rząd Litwy rozpoczął reformę przedsiębiorstw zarządzanych przez państwo. Można ją podzielić na trzy podstawowe etapy.

\subsection{Określenie najważniejszych kierunków zmian}

Dokonując zmian w przedsiębiorstwach zarządzanych przez państwo, Rząd sformułował cztery podstawowe kierunki przekształceń ${ }^{28}$ :

1) określenie wyraźnych celów PZP

Przedsiębiorstwo zarządzane przez państwo powinno obliczyć docelowy zwrot z kapitału, ocenić poziom ambicji dotyczących celów strategicznych oraz wdrożyć monitoring. Reforma zobowiązała też dziesięć największych przedsiębiorstw zarządzanych przez państwo do przygotowania długoterminowych strategii działalności, w których każde z nich określało cele działalności i finansowe oraz zakładało, w jaki sposób i kiedy powinny one zostać osiągnięte. Strategie te miały też ujawnić długotrwałą misję i wizję przedsiębiorstw oraz służyć jako narzędzie oceny pracy zarządu i kierownictwa.

28 W 2005 r. OECD opublikowało zestaw rekomendacji dotyczących zwiększenia skuteczności PZP, w których wydzielono takie podstawowe kierunki zwiększania skuteczności działalności, jak: 1) sformułowanie jasnych celów działalności przedsiębiorstwa; 2) odzielenie funkcji dotyczących własności państwa od funkcji regulacyjnych; 3) przejrzystość działalności przedsiębiorstw. Należy zatem stwierdzić, że określone na Litwie kierunki reformy w istocie odpowiadają zaleceniom OECD. 
2) ocena kosztów niekomercyjnych funkcji przedsiębiorstw oraz oddzielenie funkcji komercyjnych od niekomercyjnych

Od chwili odrodzenia niepodległości nie było jasne, jaki jest zakres funkcji niekomercyjnych PZP i jaki jest tego koszt. Dlatego niemożliwe było ustalenie, czy przedsiębiorstwa skutecznie wykonują i finansują funkcje niekomercyjne. Mając na celu rozwiązanie tych problemów, Rząd zachęcił wszystkie PZP do jasnego określenia swoich funkcji niekomercyjnych i zarazem wskazania ich kosztów. Na podstawie informacji uzyskanych od PZP będą opracowywane najlepsze modele ich finansowania. Po dokonaniu optymalizacji finansowania funkcji niekomercyjnych można będzie zaoszczędzić środki i zwiększyć jakość świadczonych usług, poprawiając w ten sposób skuteczność działalności PZP.

3) oddzielenie funkcji zarządzania przedsiębiorstwami od funkcji regulacji rynku

Kontrolując PZP, państwo często znajduje się w dwuznacznej sytuacji: z jednej strony, jest akcjonariuszem PZP (przez określone organy), z drugiej reguluje poszczególne sektory rynku (przez inne organy), w których działają zarządzane przez nie przedsiębiorstwa. Dochodzi zatem do konfliktu interesów, do rozwiązania którego dąży się poprzez oddzielenie zarządzania przedsiębiorstwami od kontroli rynkowej.

Celem reformy jest przyciągnięcie do zarządów, rad nadzorczych i na stanowiska kierowników najwyższego szczebla PZP większej liczby niezależnych kompetentnych specjalistów, którzy mogą zapewnić, by przedsiębiorstwo działało skuteczniej i w sposób ukierunkowany dążyło do zrealizowania opracowanej strategii. Zakłada się, że przynajmniej połowa członków zarządów i rad nadzorczych wszystkich przedsiębiorstw państwowych powinna spełniać kryterium niezależności - być nie urzędnikami państwowymi czy pracownikami przedsiębiorstw państwowych, lecz wykwalifikowanymi profesjonalistami, zatrudnionymi w sektorze prywatnym, znającymi rynek, na którym działa przedsiębiorstwo państwowe, posiadać wiedzę z zakresu finansów i planowania strategicznego.

W opisie realizacji praw majątkowych i niemajątkowych państwa w przedsiębiorstwach zarządzanych przez państwo imperatywnie określono, że „mając na celu uniknięcie konfliktu interesów w organach reprezentujących państwo, funkcje związane $\mathrm{z}$ reprezentowaniem państwa $\mathrm{w}$ przedsiębiorstwach zarządzanych przez państwo powinny być skupione w tych jednostkach, które nie zajmują się kształtowaniem polityki gospodarczej lub nie pełnią funkcji organizowania, koordynowania i kontroli jej realizacji”29.

29 Opis realizacji praw majątkowych i niemajątkowych państwa w przedsiębiorstwach zarządzanych przez państwo, „Valstybės žinios” z 2012 r., nr 67-3394, https://www.e-tar.lt/portal/ It/legalAct/TAR.6AF226769DB2/dFbRtUTQLV (dostęp: 10.06.2018). 
4) zwiększenie przejrzystości działalności przedsiębiorstw PZP powinny przygotowywać raporty z działalności, oceniać wyniki finansowe i skuteczność, analizować wynagrodzenie kierownictwa.

\subsection{Przyjęcie aktów prawnych niezbędnych do przeprowadzenia reformy}

Jak wskazano w postanowieniu z dnia 1 grudnia 2010 r. w sprawie zatwierdzenia koncepcji zwiększenia skuteczności przedsiębiorstw zarządzanych przez państwo $^{30}$, przyczyną nieskuteczności działalności PZP jest system zarządzania nimi, który nie zachęca do rentownej działalności, stawia przed PZP sprzeczne cele i w taki sposób stwarza nieodpowiednie warunki do zarządzania. Podobnie jak $\mathrm{w}$ wielu innych państwach, na Litwie powiązania przedsiębiorstw państwowych z Rządem są dość ścisłe, ich podwładność konkretnym ministerstwom chroni wiele przedsiębiorstw przed konkurencją zewnętrzną. Chociaż najważniejsza funkcja ministerstw powinna polegać na regulowaniu działalności poszczególnych gałęzi gospodarki, to ministerstwa często biorą aktywny udział w zarządzaniu PZP działającymi w regulowanym przez nie sektorze gospodarki. Takie postępowanie ministerstw zmniejsza przejrzystość działalności PZP i pogarsza ich wyniki finansowe, prowadząc do nieuniknionego konfliktu interesów. Dlatego też Rząd zatwierdził koncepcję zwiększenia skuteczności przedsiębiorstw zarządzanych przez państwo $^{31}$, której celem jest przekształcenie zarządzania PZP - zapewnienie, by mogły działać na takich samych warunkach rynkowych, jak przedsiębiorstwa prywatne, a także stworzenie możliwości prowadzenia działalności bez zniekształcania środowiska konkurencyjnego. Wskutek zwiększenia konkurencji PZP powinny dążyć do tego, by należący do nich majątek był użytkowany bardziej odpowiedzialnie i racjonalnie. We wspomnianym postanowieniu Rządu określono kierunki zmian w zarządzaniu PZP, mając na celu zwiększenie skuteczności ich działalności, ustalono zasady reformy i oczekiwane wyniki. Model skuteczniejszego zarządzania przedsiębiorstwami państwowymi nie tylko będzie wiązał się z korzyścią finansową dla budżetu państwa, ale też poprawi jakość usług świadczonych mieszkańcom. Ponadto, właściwe zarządzanie przedsiębiorstwami państwowymi pozytywnie wpłynie na gospodarkę kraju, polepszy otoczenie biznesowe i zwiększy atrakcyjność Litwy dla inwestorów zagranicznych. Skuteczniej zarządzane przedsiębiorstwa będą mogły łatwiej przyciągnąć inwestorów.

Należy zatem stwierdzić, że Rząd podjął inicjatywę przekształcenia zarządzania PZP, mając na celu zapewnienie uczciwej konkurencji z prywatnymi podmiota-

30 Postanowienie Rządu Republiki Litewskiej w sprawie zatwierdzenia koncepcji zwiększenia skuteczności przedsiębiorstw państwowych...

31 Ibidem. 
mi gospodarczymi, co zmusi PZP do „podciągnięcia się," wskutek czego zaczną one świadczyć konsumentom usługi lepszej jakości i zwiększą wpływy do budżetu państwa.

Innym ważnym dla reformy dokumentem są przyjęte przez rząd w $2010 \mathrm{r}$. wytyczne dotyczące zapewnienia przejrzystości działalności przedsiębiorstw państwowych (dalej: wytyczne dotyczące przejrzystości) ${ }^{32}$. Przeznaczeniem wytycznych jest zwiększenie przejrzystości w działalności PZP, odpowiedzialności względem społeczeństwa litewskiego, atrakcyjności dla inwestorów i ewentualnych partnerów biznesowych, jak również stworzenie warunków wdrożenia uznanych na świecie zasad dobrego zarządzania - opracowywanie i ogłaszanie szczegółowych informacji o działalności i wynikach przedsiębiorstw zarządzanych przez państwo (pkt 1 wytycznych dotyczących przejrzystości). W wytycznych określono podstawowe wymagania wobec ujawniania wyników działalności PZP. Ponadto Ministerstwo Gospodarki zostało wyznaczone do nadzoru nad realizacją wytycznych dotyczących przejrzystości oraz opracowania raportów z wyników działalności PZP. W punkcie 3 wytycznych określono, że „Jednym z najważniejszych celów Rządu Republiki Litewskiej jest zwiększenie przejrzystości działalności przedsiębiorstw państwowych i podjęcie działań na rzecz wdrożenia w nich zasad dobrego zarządzania. Zarządzanie tymi przedsiębiorstwami powinno opierać się na zasadach otwartości, aktywnego udziału w zarządzaniu kapitałem i dobrego zarządzania. Powinny one tworzyć wartość. Ponadto, przedsiębiorstwom państwowym nie powinny być stwarzane szczególne warunki”.

W czerwcu 2012 r. Rząd zatwierdził opis trybu realizacji praw majątkowych i niemajątkowych państwa w przedsiębiorstwach państwowych (dalej: wytyczne dotyczące własności $)^{33}$, w którym przewidziano utworzenie Centrum Koordynacji Zarządzania (dalej: CKZ), opracowanie kryteriów dotyczących kompetencji i niezależności zarządów, określenie najwyższych celów wobec PZP i sposobów ich realizacji. Wobec wytycznych dotyczących własności podjęto decyzje, jakie zasady powinny być stosowane przy ustalaniu celów strategicznych i finansowych, mianowaniu członków zarządu, zasadę oddzielenia funkcji regulacyjnej od własnościowej i inne. W wytycznych dotyczących własności określono trzy istotne działania na rzecz wzmocnienia zarządzania PZP: silny akcjonariusz, silne kierownictwo przedsiębiorstwa i jasne cele.

W 2015 r., dążąc do wzmocnienia zasad niezależności oraz tworzenia zarządów i rad nadzorczych, Rząd przyjął postanowienie w sprawie zatwierdzenia opisu doboru kandydatów na stanowiska członków zarządu przedsiębiorstwa państwowe-

32 Wytyczne dotyczące zapewnienia przejrzystości działalności przedsiębiorstw państwowych, „Valstybės žinios” z 2010 r., nr 88-4637, https://www.e-tar.lt/portal/lt/legalAct/TAR.F4AB9539E95E/qZKAcYSiHN (dostęp: 10.06.2018).

33 Opis trybu realizacji praw majątkowych i niemajątkowych państwa w przedsiębiorstwach państwowych, „Valstybės žinios” z 2012 r., nr 67-3394, https://www.e-tar.lt/portal/lt/legalAct/TAR.6AF226769DB2/ZlegesiYBF (dostęp: 10.06.2018). 
go lub samorządowego oraz kandydatów do wybieranego przez walne zgromadzenie akcjonariuszy spółki państwowej lub samorządowej organu nadzorczego lub zarządzającego ${ }^{34}$ (dalej: wytyczne dotyczące doboru), które później uzupełniono o postanowienia z wytycznych dotyczących własności. Wytyczne dotyczące doboru formalizują proces selekcji, określają skład organów kolegialnych PZP, wymagania wobec kandydatów i inne.

\subsection{Utworzenie Centrum Koordynacji Zarządzania}

Sprawdzone $\mathrm{w}$ ciągu ostatnich kilku dziesięcioleci w różnych państwach świata mechanizmy nadzoru i kontroli PZP w zasadzie można podzielić na trzy kategorie: zdecentralizowany (model tradycyjny), dualistyczny (obejmuje elementy modelu zdecentralizowanego i scentralizowanego) oraz scentralizowany (,nowy” model):

1) zgodnie z modelem zdecentralizowanym przedsiębiorstwami zarządzają odpowiednie ministerstwa nadzorujące poszczególne sektory; jego zasadniczą wadą jest słaba skuteczność w oddzielaniu funkcji państwa jako właściciela i regulatora rynku;

2) według dualistycznego modelu w poszczególnych państwach przedsiębiorstwami zarządzają ministerstwa, jednak cały system jest koordynowany przez jeden organ - zajmuje się on organizowaniem współpracy, określaniem polityki zarządzania i specyficznymi wytycznymi dotyczącymi działalności;

3) model scentralizowany oznacza zarządzanie przedsiębiorstwami przez jeden organ, np. wyspecjalizowaną agencję; model ten jest uznawany za najbardziej skuteczny, gdyż pozwala na jasną identyfikację funkcji zarządzania i ich oddzielenie od funkcji realizacji polityki ${ }^{35}$.

Mając na celu konsekwentne i profesjonalne zarządzanie PZP, rząd podjął decyzję o kierowaniu się zasadami dualistycznego modelu zarządzania przedsiębiorstwami i utworzeniu organu koordynującego działalność PZP - Centrum Koordynacji Zarządzania (CKZ), czyli organu monitorującego i analizującego realizację polityki państwa $\mathrm{w}$ przedsiębiorstwach zarządzanych przez państwo. W wytycznych dotyczących własności pełnienie funkcji CKZ powierzono przedsiębiorstwu państwowemu Państwowy Fundusz Majątkowy, w którym we wrześniu 2012 r. został utworzony specjalny wydział. Dnia 1 października 2014 r. Państwowy Fun-

34 Postanowienie Rządu Republiki Litewskiej w sprawie zatwierdzenia opisu doboru kandydatów na stanowiska członków zarządu przedsiębiorstwa państwowego lub samorządowego oraz kandydatów do wybieranego przez walne zgromadzenie akcjonariuszy spółki państwowej lub samorządowej organu nadzorczego lub zarządzającego z 23 czerwca 2015 r., TAR, nr 10088, https://e-seimas.lrs.lt/portal/legalAct/lt/TAD/f0173961199a11e5bfc0854048a4e288?jfwid=qjs00eyav (dostęp: 10.06.2018). 
dusz Majątkowy przyłączono do przedsiębiorstwa państwowego Bank Majątkowy, któremu powierzono funkcje CKZ. Po znowelizowaniu wytycznych dotyczących własności, od 1 lipca 2017 r. funkcje CKZ pełni Agencja Monitorowania i Prognoz, podległa Ministerstwu Gospodarki Litwy.

W wytycznych dotyczących własności określono podstawowe funkcje CKZ: centrum zostało zobowiązane do koordynowania wdrożenia dobrej praktyki planowania strategicznego $\mathrm{w}$ przedsiębiorstwach zarządzanych przez państwo, oceny ambicyjności postawionych przez PZP strategicznych celów, monitorowania wskaźników wdrożenia strategii oraz określenia wskaźników docelowego zwrotu z kapitału własnego PZP, a także oceny ich osiągnięć. Poza ustalonymi w wytycznych dotyczących własności funkcjami CKZ analizuje ono również informacje finansowe i niefinansowe PZP, tendencje w działalności tych przedsiębiorstw, podaje do wiadomości publicznej uogólnione sprawozdania z działalności PZP oraz prognozuje dywidendę i wpłaty z zysku PZP, wypowiada się w kwestiach określenia dywidendy $\mathrm{i}$ wpłat $\mathrm{z}$ zysku. CKZ bierze też udział $\mathrm{w}$ procesie nominacji niezależnych członków kolegialnych organów nadzoru i zarządzających: uczestniczy w pracy komisji konkursowej, doradza organom reprezentującym państwo w sprawach określenia szczególnych wymogów wobec kandydatów. Ocenia także przestrzeganie wytycznych dotyczących własności i przejrzystości oraz przedkłada swoją opinię i rekomendacje Rządowi ${ }^{36}$.

\section{Wady reformy}

Analizując działania rządu w przekształcaniu PZP, można zauważyć pozytywne i negatywne ich aspekty. Poniżej omówiono je bardziej szczegółowo.

\subsection{Brak mechanizmu zapewniającego nadzór nad polityką działalności PZP}

Przede wszystkim widoczne jest to w niekonsekwencji przyjmowania aktów prawnych regulujących działalność PZP. Dla przykładu, 9 lutego 2011 r. Rząd zatwierdził postanowieniem program przekształcenia przedsiębiorstw państwowych na lata 2011-2012, w którym wyraźnie określił cele i działania zaplanowane we wskazanym okresie. Mimo że reforma PZP jeszcze nie została zakończona, nie przyjęto kolejnych aktów prawnych, regulujących dalszy przebieg przekształceń. Poza tym zawarte we wspomnianym postanowieniu Rządu z 2011 r. rekomenda-

36 Valstybès valdomos imonès... 
cje dotyczące przygotowania podziału funkcji komercyjnych i niekomercyjnych przedsiębiorstw państwowych, określenia funkcji niekomercyjnych, ustalenia ich cen nie zostały przyjęte. Inna nieścisłość w zakresie stanowienia prawa, która przyciąga uwagę, wiąże się z tym, że Rząd nie aktualizował konsekwentnie wytycznych dotyczących własności, tj. zawarta w załączniku nr 1 do wytycznych dotyczących własności lista PZP do 24 marca 2017 r. nie była aktualizowana - znajdowały się na niej PZP zlikwidowane, sprywatyzowane lub takie, których status prawny uległ zmianie (w chwili obecnej lista ta jest nieważna, jedynym źródłem informacji pozostaje strona internetowa Agencji Monitorowania i Prognoz $\left.{ }^{37}\right)$. Podane przykłady pokazują, że Rząd nie opracował mechanizmu zapewnienia rewizji polityki działalności PZP.

\subsection{Forma prawna PZP nie odpowiada celom stawianym przez państwo}

Liczba PZP w latach 2015-2017 stale malała. Zgodnie z danymi z końca 2017 r. państwo litewskie było właścicielem lub głównym akcjonariuszom 108 PZP, a wartość księgowa ich majątku sięgała 9,3 mld euro.

Tabela 1. Liczba przedsiębiorstw zarządzanych przez państwo (szt.)

\begin{tabular}{|c|c|c|c|c|c|c|}
\cline { 2 - 7 } \multicolumn{1}{c|}{} & $\mathbf{2 0 1 5}$ & $\mathbf{2 0 1 6}$ & $\mathbf{2 0 1 7}$ & $\mathbf{2 0 1 8}$ & $\mathbf{2 0 1 9}$ & $\mathbf{2 0 2 0}$ \\
\hline Plan & & & 116 & 60 & 40 & 30 \\
\hline Fakt & 128 & 118 & 108 & & & \\
\hline
\end{tabular}

Źródło: dane Agencji Monitorowania i Prognoz.

Jak już zostało wspomniane, według formy prawnej wszystkie PZP są dzielone na przedsiębiorstwa państwowe i państwowe spółki akcyjne oraz spółki $\mathrm{z}$ ograniczoną odpowiedzialnością, które prowadzą działalność w różnych ważnych dla państwa gałęziach gospodarki (energetyka, transport, leśnictwo i inne). Państwowe spółki akcyjne i spółki z ograniczoną odpowiedzialnością są prywatnymi osobami prawnymi o ograniczonej odpowiedzialności cywilnej, w których państwo jest posiadaczem wszystkich akcji lub ich części. W I kwartale 2017 r. na Litwie status spółek akcyjnych miało 13, zaś spółek z ograniczoną odpowiedzialnością - 27 PZP. Przedsiębiorstwa państwowe to PZP posiadające formę prawną, publiczne organy prawne o ograniczonej odpowiedzialności cywilnej, utworzone na bazie majątku państwowego lub przedsiębiorstwa przekazane państwu w trybie określonym

37 Lista przedsiębiorstw zarządzanych przez państwo: https://vkc.sipa.lt/apie-imones/vvi-sarasas (dostęp: 10.06.2018). 
przepisami prawa, które są własnością państwa oraz zarządzają, użytkują i dysponują przekazanym im i nabytym majątkiem na prawie powierniczym. W I kwartale 2017 r. formę prawną przedsiębiorstw państwowych miało 78 PZP. Warto dodać, że od 2003 r. liczba przedsiębiorstw państwowych stale malała: w 2003 r. było ich 298, w 2008 r. - 108, w I kwartale 2017 r., jak już wspomniano, 78 (w tym 11 regionalnych przedsiębiorstw drogowych, 42 nadleśnictwa i 25 innych przedsiębiorstw państwowych). Mimo wszystko ta liczba nadal jest dość duża ${ }^{38}$.

Należy podkreślić, że OECD zaleca ${ }^{39}$ uproszczenie i ujednolicenie form prawnych przedsiębiorstw państwowych, tj. określenie, że podstawowa działalność przedsiębiorstw państwowych jest gospodarczo-handlowa i przekształcenie ich w spółki z ograniczoną odpowiedzialnością, tj. dążenie do aktywniejszej zmiany formy na spółkę.

W kwietniu 2017 r. Urząd Kontroli Państwowej w opinii z audytu „Zwrot dla państwa z przedsiębiorstw zarządzanych przez państwo" surowo skrytykował bezczynność Rządu w dziedzinie polityki zarządzania PZP, ponieważ po przeprowadzeniu w 2009 r. audytu „Zarządzanie przedsiębiorstwami państwowymi” Urząd Kontroli Państwowej przedstawił Rządowi rekomendacje, proponując wyraźne określenie, które PZP koniecznie należy zreformować oraz możliwie najszybszą zmianę formy prawnej pozostałych PZP, których działalność nie jest zgodna $\mathrm{z}$ ustalonymi celami.

Należy wspomnieć, że 10 stycznia 2018 r. Rząd poparł przedstawiony przez Ministerstwo Gospodarki plan przekształcenia przedsiębiorstw zarządzanych przez państwo. Postanowiono przekształcić jedenaście przedsiębiorstw państwowych w spółki akcyjne lub spółki z ograniczoną odpowiedzialnością, zlikwidować cztery przedsiębiorstwa państwowe, a do wykonania ich funkcji powołać cztery organizacje pożytku publicznego, natomiast pięć przedsiębiorstw państwowych zachowało swoją formę prawną. Warto wspomnieć, że jedenaście przedsiębiorstw utrzymania dróg połączono $\mathrm{w}$ jedno przedsiębiorstwo państwowe. Od 8 stycznia 2018 r. jedno przedsiębiorstwo państwowe stanowią 42 nadleśnictwa oraz Instytut Gospodarki Leśnej ${ }^{40}$. Plan środków przekształcenia przedsiębiorstw zarządzanych przez państwo został zatwierdzony przez Rząd protokołem uchwały, która nie ma mocy aktu prawnego i nie została ogłoszona publicznie, dlatego nie może zostać zaskarżona na drodze sądowej. Uchwała ta budzi wątpliwości co do przejrzystości omawianej reformy.

38 Opinia z audytu Urzędu Kontroli Państwowej „Zwrot dla państwa z przedsiębiorstw zarządzanych przez państwo" z 25 kwietnia 2017 r., VA-2017-P-20-3-10, s. 17.

39 OECD Review of the Corporate Governance of State-Owned Enterprises: Lithuania, 2015, http:// www.oecd.org/daf/ca/Lithuania_SOE_Review.pdf (dostęp: 10.06.2018).

40 Ministerstwo Gospodarki, Przedstawiony plan restrukturyzacji przedsiębiorstwa państwowego, https://ukmin.lrv.lt/lt/naujienos/pristatytas-valstybes-imoniu-pertvarkos-planas (dostęp: 10.06.2018). 


\subsection{Niewystarczająco wyraźnie określone cele przedsiębiorstw zarządzanych przez państwo}

Dążąc do właściwej realizacji projektów o znaczeniu strategicznym dla bezpieczeństwa narodowego, a zarazem zapewnienia wzrostu wartości przedsiębiorstw i odpowiedniego zwrotu $z$ inwestycji państwowych, jak również należytej i przejrzystej realizacji zadań społecznych i politycznych, państwo jest obowiązane określić wyraźne cele związane $\mathrm{z}$ udziałem $\mathrm{w}$ działalności przedsiębiorstw zarządzanych przez państwo i przedstawić społeczeństwu argumenty na to, dlaczego udział państwa w zarządzaniu PZP jest konieczny ${ }^{41}$. W taki sposób w gospodarce rynkowej zapewnia się pierwszeństwo przedsiębiorstw prywatnych w prowadzeniu działalności gospodarczej. Na podstawie wytycznych dotyczących własności wszystkie PZP, poczynając od 2012 r., zostały podzielone na grupy według postawionych przez państwo celów: grupa 1A (cel: wzrost wartości przedsiębiorstwa oraz dochodowości dywidendy i zysku; np. UAB LITEXPO), grupa 1B (cel: wzrost wartości przedsiębiorstwa oraz dochodowości dywidendy i zysku oraz zabezpieczenie strategicznych interesów kraju; np. UAB Lietuvos energija, AB Klaipedos nafta, AB Lietuvos geležinkeliai)) i grupa 2 (cel: realizacja zadań społecznych i politycznych, tj. przedsiębiorstwo prowadzi działalność o charakterze niekomercyjnym, czyli taką, której nie podjęłyby się inne podmioty gospodarcze o celu zarobkowym lub koszt takiej działalności w ich przypadku byłby wyższy, z kolei działalność komercyjną prowadziłyby wyłącznie w przypadku, gdyby nie przeszkadzało to w dążeniu do określonych przez państwo celów społecznych i politycznych; np. przedsiębiorstwo państwowe Elektrownia Atomowa w Ignalinie, przedsiębiorstwo państwowe Litewska Agencja Produktów Naftowych). Prawidłowy, jasny i przejrzysty podział przedsiębiorstw na grupy (1A, 1B i 2) jest ważny, gdyż od tego zależy, czego państwo oczekuje od każdego konkretnego PZP. Na przykład w przypadku PZP zaliczanych do grup 1A i 1B na trzyletni okres ustalano średnią docelową cenę kapitału własnego, zaś w przypadku PZP zaliczanych do grupy $2^{42}$ taki docelowy wskaźnik nie był określany, dlatego przydzielenie PZP do grupy 2 stało się wadliwą praktyką, a działalność PZP była pozbawiona ambicji ${ }^{43}$. Mając

41 Opinia z audytu Urzędu Kontroli Państwowej..., s. 17.

42 W wytycznych dotyczących własności określono, że zaliczane do grupy 2 PZP powinny prowadzić działalność niekomercyjną, tj. taką, której nie podjęłyby się inne podmioty gospodarcze o celach zarobkowych lub taką działalność prowadziłyby za wyższą cenę; z kolei działalność komercyjną prowadziłyby wyłącznie w przypadku, gdyby nie utrudniała ona dążenia do osiągnięcia określonych przez państwo celów społecznych i politycznych. Nie określono jednak kryteriów związanych ze stosunkiem dochodów z tytułu szczególnych zobowiązań do ogólnych dochodów PZP. Więcej w: Opinia z audytu Urzędu Kontroli Państwowej...

43 Na przykład AB „Lietuvos veislininkystė” zaliczono do grupy 2, gdyż w ramach realizacji celów społecznych i politycznych wykonuje szczególne zobowiązanie, jak również jej celem jest zysk. Rodzi się jednak wątpliwość, czy rzeczywiście to PZP powinno należeć do grupy 2, gdyż 
na celu naprawienie tego błędu, w 2018 r. Rząd dokonał nowelizacji wytycznych dotyczących własności, rezygnując z podziału PZP na wspomniane trzy grupy (1A, 1B i 2) ${ }^{44}$. Zgodnie z poprawkami, które weszły w życie, organ reprezentujący państwo co najmniej raz na cztery lata przygotowuje i przedkłada PZP pismo dotyczące celów państwa i oczekiwań wobec PZP (dalej: pismo). Celem pisma jest wskazanie i zidentyfikowanie celów oraz oczekiwań wobec PZP. Pismo wizuje kierownik organu reprezentującego państwo. Pismo jest przekazywane do wiadomości Centrum Koordynacji Zarządzania, które może zgłaszać uwagi. Mając na względzie dokonaną w 2018 r. nowelizację wytycznych dotyczących własności, należy stwierdzić, że rola i kompetencje Rządu w zarządzaniu oraz użytkowaniu majątku państwowego - przedsiębiorstw zarządzanych przez państwo - bardzo się zawęziły, gdyż obecnie główne decyzje podejmuje organ reprezentujący państwo, zaś Rząd jedynie zatwierdza średnie roczne docelowe ceny kapitału własnego PZP. Taka sytuacja może prowadzić do stawiania PZP sprzecznych celów, a to stwarza warunki do niewłaściwego zarządzania nimi w skali państwa. Tryb określania przedsiębiorstwom celów przewidzianych w wytycznych dotyczących własności, zarówno w 2012, jak i w 2018 r., nie zapewnia zatem tym celom przejrzystości i nie stanowi zachęty do zwiększania skuteczności działalności PZP.

\section{Wnioski}

1. W Konstytucji Republiki Litewskiej, w odróżnieniu od obowiązujących do chwili odzyskania przez Litwę niepodległości podstawowych aktów prawnych Litwy Radzieckiej, nie został określony „majątek państwowy”, jednak systemowa analiza Konstytucji Litwy i orzecznictwa stanowiącego jej wykładnię oraz zwykłych aktów prawnych pozwala na rozróżnienie własności prywatnej i publicznej. Na podstawie dokonanej analizy przepisów prawa należy stwierdzić, że majątek państwowy jest zarządzany, użytkowany i dysponowany na podstawie przyjętych przez Rząd aktów prawnych.

2. Przedsiębiorstwa zarządzane przez państwo stanowią część majątku państwa - to przedsiębiorstwa prowadzące działalność gospodarczo-handlową, wśród których można wyróżnić przedsiębiorstwa państwowe i inne, zarządzane w oparciu o kapitał akcyjny. Z jednej strony przedsiębiorstwa te są niejako prywatnymi pod-

podstawowe dochody czerpie z działalności komercyjnej, z kolei dochód z wykonania szczególnego zobowiązania wynosi poniżej $8 \%$ dochodów całkowitych. Ponieważ podstawowa działalność PZP jest komercyjna, należy przypuszczać, że to PZP powinno być zaliczone do grupy $1 \mathrm{~B}$.

44 Opis trybu realizacji praw majątkowych i niemajątkowych państwa w przedsiębiorstwach państwowych... 
miotami gospodarczymi, uczestnikami rynku dążącymi do maksymalizacji zysku, z drugiej zaś - stanowią nieodłączny składnik gospodarki państwa, który ma znaczny bezpośredni i pośredni wpływ na gospodarkę krajową, dobrobyt mieszkańców oraz tworzenie bardziej sprzyjających warunków przedsiębiorczości.

3. Analiza dokumentów przyjętych przez Rząd w ramach zainicjowanej reformy pozwala stwierdzić, że celem ogólnym reformy jest skuteczniejsza działalność przedsiębiorstw zarządzanych przez państwo. Dla osiągnięcia tego celu Rząd określił podstawowe kierunki zmian, do których należą: ocena kosztów niekomercyjnych funkcji przedsiębiorstw i oddzielenie funkcji komercyjnych od niekomercyjnych; oddzielenie funkcji zarządzania przedsiębiorstwami od funkcji regulacji rynku; zwiększenie przejrzystości działalności przedsiębiorstw. Do realizacji reformy PZP niezbędne było przyjęcie nowych aktów prawnych, m.in. zwiększających przejrzystość działalności przedsiębiorstw zarządzanych przez państwo i wdrażających uznane w świecie zasady dobrego zarządzania (tzw. wytycznych dotyczących przejrzystości); określających tryb realizacji w PZP praw majątkowych i niemajątkowych państwa (tzw. wytycznych dotyczących własności); wzmacniających zasady niezależności zarządów i rad nadzorczych PZP oraz ich wyboru (tzw. wytycznych dotyczących doboru). Mając na celu monitorowanie i analizę wdrażania polityki państwa w przedsiębiorstwach zarządzanych przez państwo, utworzono Centrum Koordynacji Zarządzania.

4. Po dokonaniu analizy realizowanej przez Rząd reformy PZP dały się dostrzec takie wady przekształceń, jak: niewystarczająco jasno określone cele przedsiębiorstw państwowych, brak mechanizmu zapewniającego rewizję polityki działalności PZP, niezgodność formy prawnej PZP ze stawianymi przez państwo celami.

\section{Santrauka}

\section{Lietuvos Respublikos Vyriausybės vykdoma valstybės valdomų imonių reforma}

Vyriausybė, kaip vykdomosios valdžios institucija, pagal Konstituciją inter alia turi plačią diskreciją formuoti ir vykdyti valstybès ekonominę politiką ir atitinkamai reguliuoti ūkinę veiklą. Konstitucijos 94 str. 1 p. nurodyta, kad Lietuvos Respublikos Vyriausybe „tvarko krašto reikalus“. Pateikiama konstitucinė formuluotė apima daug veiklos sričių nuo ekonominės politikos formavimo iki sveikatos apsaugos užtikrinimo šalyje. Vyriausybės įstatymo 22 str., konkretizuojančiame Vyriausybės veiklą, nustatyta, kad Vyriausybė remdamasi įstatymais disponuoja valstybiniu turtu, nustato jo valdymo ir naudojimo tvarką. Paminėtina, kad Lietuvos Respublikos Konstitucijoje (priešingai nei Lietuvos TSR konstitucijose) nèra ịvardintas „valstybès turtas“, tačiau sisteminė Konstitucijos, ją aiškinančios konstitucinès jurisprudencijos bei ordinarinių 
teisès aktų analizė leidžia privačios ir viešosios nuosavybės distinkciją. Vadovaujantis straipsnyje atlikta teisès aktų analize, teigtina, kad valstybès valdomas turtas yra valdomas, naudojamas ir juo disponuojama vadovaujantis iš anksto priimtais Vyriausybès teisès aktais.

Viena iš valstybès turto dalių yra valstybès valdomos įmonès, kurios skirstomos ì valstybès įmones ir kitas įmones, kurios valdomos akcinio kapitalo pagrindu. Šios įmonès yra iš vienos pusès, kaip ir privatūs ūkio subjektai, pelno maksimizavimo siekiantys rinkos dalyviai, o iš kitos pusès - neatsiejama valstybès ekonomikos sudedamoji dalis, turinti didelį tiesioginị ir netiesioginị poveikị šalies ekonomikai, gyventojų gerovei bei palankesnių verslo sąlygu kūrimui. 2010 metais pirmą kartą paskelbta valstybès valdomo komercinio naudojimo turto apžvalga atskleide, kad daugumos valstybès valdomų įmonių veiklos rezultatai buvo prasti. Atsižvelgiant ị tai, XV Vyriausybe pradejjo vykdyti šių įmonių pertvarką, kurios tikslas buvo siekti efektyvesnès valstybès valdomų įmonių veiklos. Šiame straipsnyje yra analizuojami valstybės valdomų i̇monių, kaip valstybinio turto dalies, ir šių ¿̇monių Vyriausybės vykdomos reformos juridiniai pagrindai bei atkleidžiami vykdomos pertvarkos trūkumai. Atlikta analizè išryškino tokius vykdomos pertvarkos trūkumus, kaip nepakankamai aiškiai nustatyti valstybès valdomų i̇monių tikslai, šių i̇monių veiklos politikos peržiūros užtikrinančio mechanizmo nebuvimas bei valstybès valdomų įmonių teisinès formos neatitikimas valstybès keliamiems tikslams.

\section{Literatura}

Anužis M., Sinkevičius V., Valstybès valdomos imonès. Nepriklausomy valdybos nariu atrankos gairés, nuosavybès gairiu analize ir atitiktis EBPO gairems, Vilnius 2015.

Beinoravičius D. et al., Lietuvos konstitucine teise, Vilnius 2017.

Hauser R., Niewiadomski Z., Wróbel A. (red.), Publiczne prawo gospodarcze. System prawa administracyjnego, t. 8A, Warszawa 2018.

Jurkonis L., Valstybès valdomy imoniu valdymo kontrolès ir autonomijos poveikis veiklos efektyvumui, „Politologija” 2012, nr 2 (66).

Juškevičiūtè-Vilienè A., Asmens ūkinès veiklos laisvès konstituciniai pagrindai Lietuvoje: ekonomines, istorines ir lyginamosios jžvalgos, Vilnius 2017.

Mažylytė L., Valstybès valdomu įmonių vaidmuo ES vidaus rinkos kontekste, 2013, http://www. esrinka.lt/download/275/straipsnis_konkurencingumas_vvi.pdf (dostęp: 23.06.2018).

OECD Review of the Corporate Governance of State-Owned Enterprises: Lithuania, 2015, http://www.oecd.org/daf/ca/Lithuania_SOE_Review.pdf (dostęp:10.06.2018).

Tittenbrun J., Przedsiębiorstwo publiczne w ujęciu teorii praw własnościowych, „Ruch Prawniczy, Ekonomiczny i Socjologiczny” 1996, t. 3.

Vaitkevičius S., Birštonas R., Valstybinio turto valdymas ir privatizavimas 1992-2012 metais, VI „Registrų centras”, Vilnius 2015. 


\section{Akty prawne}

Ustawa o zarządzaniu, wykorzystywaniu i dysponowaniu majątkiem państwowym i samorządowym, „Valstybės žinios” z 1994 r., nr IX-1895; „Valstybės žinios” z 2004 r., nr 4-24.

Postanowienie Rządu Republiki Litewskiej w sprawie zatwierdzenia koncepcji zwiększenia skuteczności przedsiębiorstw państwowych z 1 grudnia 2010 r., nr 1731, „Valstybės žinios" z 2010 r., nr 145-7447.

Postanowienie Rządu Republiki Litewskiej w sprawie zatwierdzenia opisu doboru kandydatów na stanowiska członków zarządu przedsiębiorstwa państwowego lub samorządowego oraz kandydatów do wybieranego przez walne zgromadzenie akcjonariuszy spółki państwowej lub samorządowej organu nadzorczego lub zarządzającego z 23 czerwca 2015 r., TAR, nr 10088, https://e-seimas.lrs.lt/portal/legalAct/lt/TAD/f0173961199a11e5bfc0854048a4e288?jfwid=qjs00eyav (dostęp: 19.05.2018).

Wytyczne dotyczące zapewnienia przejrzystości działalności przedsiębiorstw państwowych, „Valstybės žinios” z 2010 r., nr 88-4637, https://www.e-tar.lt/portal/lt/legalAct/ TAR.F4AB9539E95E/qZKAcYSiHN (dostęp: 10.06.2018).

Opinia z audytu Urzędu Kontroli Państwowej „Zwrot dla państwa z przedsiębiorstw zarządzanych przez państwo" z 25 kwietnia 2017 r., VA-2017-P-20-3-10.

Opis realizacji praw majątkowych i niemajątkowych państwa w przedsiębiorstwach zarządzanych przez państwo, „Valstybės žinios” z 2012 r., nr 67-3394, https://www.e-tar.lt/ portal/lt/legalAct/TAR.6AF226769DB2/dFbRtUTQLV (dostęp: 21.06.2018).

Opis trybu realizacji praw majątkowych i niemajątkowych państwa w przedsiębiorstwach państwowych, „Valstybès žinios” z 2012 r., nr 67-3394, https://www.e-tar.lt/portal/lt/ legalAct/TAR.6AF226769DB2/ZlegesiYBF (dostęp: 23.06.2018).

\section{Orzecznictwo Sądu Konstytucyjnego}

Orzeczenie Sądu Konstytucyjnego Republiki Litewskiej z 27 maja 2002 r.

Orzeczenie Sądu Konstytucyjnego Republiki Litewskiej z 13 grudnia 2004 r.

Orzeczenie Sądu Konstytucyjnego Republiki Litewskiej z 23 maja 2007 r.

Orzeczenie Sądu Konstytucyjnego Republiki Litewskiej z 30 listopada 2008 r.

\section{Strony internetowe}

Lista przedsiębiorstw zarządzanych przez państwo, https://vkc.sipa.lt/apie-imones/vvi-sarasas (dostęp: 10.06.2018).

Ministerstwo Gospodarki, Przedstawiony plan restrukturyzacji przedsiębiorstwa państwowego, https://ukmin.lrv.lt/lt/naujienos/pristatytas-valstybes-imoniu-pertvarkos-planas (dostęp: 10.06.2018).

State-Owned Enterprises in the European Union: ensuring level playing field, Raport, http:// www.esparama.lt/es_parama_pletra/failai/ESFproduktai/2_UM_valstybes-valdomos-imones_2013-03.pdf (dostęp: 25.06.2018).

Valstybès valdomos įmonès, Raport, http://www.vkc.sipa.lt/static/uploads/VKC_2016_LT_ A4_WEB.pdf (dostęp: 21.06.2018). 